\title{
Influence of Social Media on Sexual Behaviour of Youth in Kwara State, Nigeria: Implications for Counselling Practice
}

\author{
Lateef Omotosho Adegboyega
}

\begin{abstract}
This study investigated the influence of social media on the sexual behaviour of youth in Kwara State. Descriptive research design was adopted for the study. A total of 395 youth participated in the study. One research question was raised while three null hypotheses were formulated and tested at 0.05 level of significance. The instrument used for data collection for this study was a researcher-designed questionnaire entitled "Influence of Social Media Questionnaire" (ISMQ). The findings revealed that social media has considerable influence on the sexual behaviour of youth in Kwara State. Social media leads students to the act of sending erotic messages, watching pornographic films and movies, and also increases risky sexual behaviour such as masturbation. There were no significant differences in the influence of social media on sexual behaviour of youth in Kwara State based on gender, age and university attended. It was therefore recommended that counsellors should expose students to the danger inherent in negative uses of social media and analyze the possible result of proper usage of social media. Counsellors should also provide information specifically on the safe and respectful use of technology, as well as consequences of the negative use of social media to students of different genders, ages and universities attended.
\end{abstract}

Lateef Omotosho Adegboyega, a Lecturer in the Department of Counsellor Education, University of Ilorin, Nigeria obtained his Doctor of Philosophy (Ph.D.) (2017) in Educational Guidance and Counselling from the University of Ilorin, Nigeria. Adegboyega is a registered teacher with the Teachers' Registration Council of Nigeria (TRCN). He is a member of the Counselling Association of Nigeria and a member of the Association of Professional Counsellors in Nigeria. He is also a Licensed Professional Counsellor of Nigeria (LPCN) and Certified Counsellor of Nigeria (CCN). Recent Publications include:

Recent Publications:

Adegboyega, L. O. (2017). Counselling needs of youth at University of Ilorin, Ilorin, Nigeria. KIU Journal of Humanities, 2(2B), 49-58. Available online at http://ijhumas.com/ojs/index.php/kiuhums/article/view/153/140

Adegboyega, L. O. \& Jacob, O. A. (2017). Causes of premarital sex as expressed by youth in Yagba West, Kogi State, Nigeria. Anatolian Journal of Education, 2(2), 8-20. (A Journal of the Faculty of Education, Eskisehir Osmangazi University, Turkey). Available online at http://e-aje.net/images/dosyalar/AJE_17_2_2.pdf 
Adegboyega

Adegboyega, L. O. (2018). Influence of achievement motivation on Nigerian youth' attitude

towards examination. International Journal of Instruction, 11(1), 77-88. (A Journal of the Faculty of Education, Eskisehir Osmangazi University, Turkey). Available online at http://www.e-iji.net/dosyalar/iji_2018_1_6.pdf 
The Influence of the Social Media on the Sexual Behavior of Youth in Kwara State, Nigeria

\section{Introduction}

Sexuality is the quality or state of being sexual. Sexuality is not merely the absence of disease, dysfunction, or infirmity. Sexual health requires a positive and respectful approach to sexuality and sexual relationships, as well as the possibility of having pleasurable and safe sexual experiences, free of coercion, discrimination, and violence (WHO, 2012). The key markers and indicators of sexual risk behaviour (SRB) include an early age of sexual initiation, inadequate contraception use, promiscuous behavior, and sexual contact with an unknown partner (Kirby, Raine, Thrush, Yuen, Sokoloff \& Potter, 2010). According to Onwuasoaya (2008), sex is the action of a man inserting his penis into a woman's vagina, usually leading to the release of semen from the penis, as a result of which the woman may become pregnant. In the same vein, Onwuasoaya (2008), defined behaviour as the way that someone conducts himself. Behaviour can either be good or bad, desirable or undesirable.

Deczrlo (2009) pointed out that sexually explicit movies expose young people to adult issues at an impressionable age. Others opined that the use of pornographic materials as well as knowledge and use of contraceptives, especially the condom that has been excessively advertised, has contributed immensely to the involvement of youth in sexual practices. A study was carried out by Emma, Walker, Zaba and Collumbian (2009). The study was undertaken amongst students in a tertiary institution to ascertain the risky sexual behaviours amongst them so as to suggest solutions on how to remedy the problem. The National Population Commission (NPC) (2015) reported that $68.8 \%$ sexually active respondents is higher than that of the report of the 2013 Nigeria National Demographic and Health Survey (NDHS) which shows that $48.9 \%$ of youth are sexually active. This may probably be due to the fact that the NDHS data is on youth (i.e. a group of individuals who were between the age bracket of 15 and 18) while the respondents in the NPC study were a group of individuals 
between the age bracket of 18 and 24 . It is worthy to note that only $35(36.8 \%)$ of the sexually active respondents in the study had only one sexual partner in the past one year. The remaining $63.2 \%$ majority were having sex with multiple partners, with as high as $27.4 \%$ having sexual intercourse with as many as six or more partners. This finding is comparable to the report from a study conducted at Ilorin, Nigeria which showed that $62.3 \%$ of tertiary students studied, had more than one sex partner (Fawole, Ogunkan \& Adegoke, 2011). The reason for multiple sexual partners may be connected to the fact that youth often engage in sexual experimentation and are often times ignorant of the associated negative consequences. Due to a lack of accurate information on sexuality and reproductive health and lack of access to reproductive health care, students are exposed to risks associated with their sexual activity. From the submissions of Braun-Courville and Rojas (2009) and Deczrlo (2009) there seems to be factors that influence youth sexual behaviour but only social media and peer pressure will be examined in this study.

Social media is a form of electronic communication which facilitates interaction based on certain interests and characteristics. Social media are platforms for social interaction, using highly accessible and scalable publishing techniques. Social media use web-based technologies to transform and broadcast media monologues into social dialogues. They support the democratization of knowledge and information and transform people from content consumers to content producers. Social media are elements of the new media and, according to Danny (2011), they have become the highest activity on the internet.

Social media is a group of internet-based applications that allow the creation and exchange of user generated content (Kaplan \& Haenlein, 2010). It allows users to meet old and new friends, exchange ideas, images, videos and audios. Examples of social media websites are Facebook, 2go, Tweeter, BBM, Skype, WhatsApp among others. However, 
social media have evolved to include other tools and practices that were not conceived of only a few years or even a few months ago. Students use social media tools for many purposes such as access to information, group discussion, resource sharing and entertainment (Wang, Chen \& Liang, 2011). This has generated speculation on their use and related positive and negative implications, in both the short and long terms. Kaplan and Haenlein (2010) opined that the roots of social media are nothing more than the internet, whereby the World Wide Web (www) served as a platform meant to facilitate exchange of information between users.

Social media (Facebook, Linkedin or Twitter) received a lot of attention due to the high take-up rate across the world. Social media have made communication, collaboration and interaction possible and more efficiently. Consequently, they have been introduced to support educational activities (Greenhow, Robelia, \& Hughes, 2009). Social media have been able to create a revolution in the communication fields for information and knowledge sharing (Greenhow, Robelia, \& Hughes, 2009). This revolution has changed the manner of how people interact and communicate with each other, including how they exchange, access and share knowledge (Redecker, Ala-Mutka, Bacigalupo, Ferrari, \& Punie, 2009). Social media technologies have several advantages such as to create new methods of interaction, collaboration, and the ability to share and create content (Harris, \& Rea, 2009). With these characteristics, social media are recognized as important tools for reshaping the learning and educational environment. By implementing e-learning tools according to the advantages of the social networking media, it can be used to provide an interactive and collaborative learning environment (Fischer \& Mandl, 2005).

Social media which were introduced more than a decade ago have drawn large 
Adegboyega

numbers of users. Boyd (2009) confirmed that the involvement of students in social media has increased considerably since 2004. Boyd (2007) reported that teenagers and students embraced social media so as to interact with peers for information sharing and to re-formulate their personalities thereby getting their social lives off the ground. It is on this premise that this study investigated the influence of social media on sexual behaviour of youth in Kwara State, Nigeria.

\section{Research Question}

The following research question was raised to guide the conduct of the study:

1. Does social media influence the sexual behaviour of youth in Kwara State, Nigeria?

\section{Hypotheses}

The following null hypotheses were formulated and tested in this study:

1. There is no significant difference in the influence of social media on sexual behaviour of youth in Kwara State based on gender.

2. There is no significant difference in the influence of social media on sexual behaviour of youth in Kwara State based on age.

3. There is no significant difference in the influence of social media on sexual behaviour of youth in Kwara State based on university attended.

\section{Methodology}

The design that was adopted for this study is the descriptive survey research method. The researchers considered the descriptive survey design method most appropriate because it entails the use of direct observation in the collection of data which was employed in finding 
The Influence of the Social Media on the Sexual Behavior of Youth in Kwara State, Nigeria

out the influence of social media on sexual behaviour of youth (undergraduates) in Kwara State, Nigeria.

The population of the study consisted of all undergraduates of universities in Kwara State while the target population was undergraduates drawn from four (4) Universities in Kwara State. The population of undergraduate students at the University of Ilorin is estimated at 35,336 (Academic Planning Unit, 2015/2016 session); Kwara State University, 8,685 (Academic Planning Unit, 2016/2017 session); Al-Hikmah University, 3000 (Academic Planning Unit, 2016/2017 session) and Landmark University, 3500 (Academic Planning Unit, 2016/2017 session). There are 50,521 youth in Kwara State. According to the Research Advisor (2006), the minimum sample size for this population is 381 , under $95 \%$ confidence level and at 5.0\% error margin. However, the researcher decided to increase this figure by 5\% which brought the sample size to 400 , in order to ensure fair representation and cater for any attrition during the course of the administration.

Multi-stage sampling procedures were used in selecting the respondents for the study. Purposive, proportional and stratified random sampling methods were used to select 400 respondents from four universities in Kwara State. In order to obtain the required sample for the study, at the first stage, purposive sampling was used to select four universities including the University of Ilorin, Ilorin, Al-Hikmah University, Ilorin; Kwara State University, and Malete and Landmark University, OmuAran. The other two Universities, which were Crown Hill University and Summit University were newly established and were yet to develop student's culture and did not form part of the sample.

At stage two, proportional sampling was used to select 400 students in the ratio 20:5:2:2, in line with the magnitude of the universities' population. For University of Ilorin 279 respondents; Kwara State University 69 respondents; Landmark University 28 
respondents; Al-Hikmah University 24 respondents. Therefore, a total number of 400 respondents were selected from four universities. At stage three, a stratified random sampling technique was used to stratify respondents on the bases of their gender, age and university attended.

The instrument that was used for the collection of data was a self-developed questionnaire entitled "Influence of Social Media Questionnaire" (ISMQ). The questionnaire consists of fifteen items on the influence of social media on sexual behaviour of youth respectively. The questionnaire was divided into two sections; A and B. Section A elicits information on the personal data of respondents such as gender, age, religious affiliation and university attended while Section B contains 15 items on the influence of social media on the sexual behaviour of youth.

The questionnaire was patterned in the form of a four-point Likert-type rating scale of SA (Strongly Agree); A (Agree); D (Disagree); and SD (Strongly Disagree)

The researcher employed both descriptive and inferential statistics for the data analysis. Percentages were used for the descriptive statistics while t-test and Analysis of Variance (ANOVA) statistical tools were employed to test the null hypotheses at 0.05 level of significance.

\section{Results}

\section{Demographic Data}

The demographic data of the respondents' entails the distribution of respondents by the variable of the study (i.e. gender, age, religious affiliation and university attended). Therefore, this section presents the results of data obtained from the respondents in percentages. 
Table 1

Distribution of Respondents by Gender, Age and University Attended

\begin{tabular}{llcc}
\hline S/N & Variables & Frequency & Percentages\% \\
\hline 1. & Gender & 204 & 51.6 \\
& Male & 191 & 48.4 \\
& Female & $\mathbf{3 9 5}$ & $\mathbf{1 0 0 . 0}$ \\
& Total & & 25.6 \\
& Age range & 101 & 58.2 \\
Below 18 years & 230 & 14.2 \\
18-25years & 56 & 2.0 \\
& 26-30years & 8 & $\mathbf{1 0 0 . 0}$ \\
Above 30years & $\mathbf{3 9 5}$ & 68.6 \\
& Total & & 6.3 \\
& University Attended & 275 & 18.0 \\
UNILORIN & 24 & 7.1 \\
& Al-HIKMAH & 68 & $\mathbf{1 0 0 . 0}$ \\
\hline
\end{tabular}

Table 1 shows the distribution of respondents by gender, age and university attended. The information on the table indicates that $204(51.6 \%)$ of the respondents were males while 191 (48.4\%) were females. Also, 101 (25.6) of the respondents were below 18 years while 230 (58.2) falls between 18 and 25 years, $56(14.2 \%)$ were between 26 and 30 years while 8 $(2.0 \%)$ of the respondents were above 30 years. Finally, the table shows that $275(68.6 \%)$ of the respondents attends University of Ilorin, 24 (6.3\%) attends Al-Hikmah University, 68 (18.0\%) attends Kwara State University while 28 (7.1\%) of the respondents attends Landmark University. 


\section{Research Question 1: Does social media influence the sexual behaviour of youth in Kwara State, Nigeria?}

Table 2

\section{Mean and Rank Order Analysis of the Influence of Social Media on the Sexual Behaviour of Youth in Kwara State}

\begin{tabular}{|c|c|c|c|}
\hline Item No. & The use of social media leads students into: & Mean & Rank \\
\hline 1 & sending erotic messages & 3.29 & $1^{\text {st }}$ \\
\hline 2 & watching pornographic films and movies & 3.29 & $1^{\text {st }}$ \\
\hline 3 & increase in risky sexual behaviour & 3.28 & $3^{\text {rd }}$ \\
\hline 4 & masturbation & 3.18 & $4^{\text {th }}$ \\
\hline 15 & involvement in pre-marital sex & 3.18 & $4^{\text {th }}$ \\
\hline 5 & prostitution & 3.14 & $6^{\text {th }}$ \\
\hline 6 & sexing & 3.14 & $6^{\text {th }}$ \\
\hline 7 & $\begin{array}{l}\text { sexual perversion (sexual activities considered outside the norm } \\
\text { of heterosexual sexual desire and activity) }\end{array}$ & 3.13 & $8^{\text {th }}$ \\
\hline 9 & involvement in phone sex & 3.10 & $9^{\text {th }}$ \\
\hline 14 & privacy violation & 3.08 & $10^{\text {th }}$ \\
\hline 11 & sexual solicitation & 3.07 & $11^{\text {th }}$ \\
\hline 12 & online sexual harassment & 3.06 & $12^{\text {th }}$ \\
\hline 13 & $\begin{array}{l}\text { involvement in gang bang (a group of individuals having } \\
\text { intercourse with one person at a time) }\end{array}$ & 3.05 & $13^{\text {th }}$ \\
\hline 8 & homosexuality & 3.03 & $14^{\text {th }}$ \\
\hline 10 & abortion & 3.03 & $14^{\text {th }}$ \\
\hline
\end{tabular}

Table 2 shows the mean and rank order analysis of response on influence of social media on the sexual behaviour of youth in Kwara State. The results on the table revealed that items 1, $2,3,4$, and 15 ranked as the top 5 items. Items 1 and 2 which states that the use of social media leads "students to send erotic messages" and "watching of pornographic films and movies" ranked $1^{\text {st }}$ with a mean score of $3.29(32.9 \%)$. Items 3 which states that use of social media lead students to" increase in risky sexual behaviour" ranked $3^{\text {rd }}$ with a mean score of $3.28(32.8 \%)$.

The results on the table further shows that item 13 which states that social media leads students to "involvement in gang bang (a group of individuals having intercourse with one person at a time)" ranked $13^{\text {th }}$ with a mean score of $3.05(30.5 \%)$ and item 8 and 10 which states that social media lead students to "homosexuality" and "abortion" ranked $14^{\text {th }}$ with a 
The Influence of the Social Media on the Sexual Behavior of Youth in Kwara State, Nigeria

mean score of $3.03(30.3 \%)$. Therefore, it can be concluded social media has considerable influence on sexual behaviour of youth in Kwara State. Social media commonly leads students to sending erotic messages, watching pornographic films and movies, an increase in risky sexual behaviour, masturbation, and involvement in pre-marital sex among others.

\section{Hypotheses Testing}

In this study, three null hypotheses were postulated and tested. The hypotheses were tested using t-test and ANOVA statistical methods at 0.05 level of significance. The results are presented thus:

Hypothesis One: There is no significant difference in the influence of social media on sexual behaviour of youth in Kwara State based on gender.

Table 3

Means, Standard Deviations and t-value of Respondent's Influence of Social Media on the Sexual Behaviour of Youth based on Gender

\begin{tabular}{llllllll}
\hline Gender & N & Mean & Std. Dev & df & Cal. t-value & Critical t-value & $\begin{array}{l}\text { p- } \\
\text { value }\end{array}$ \\
\hline & & & & & & & \\
Male & 204 & 47.14 & 7.22437 & & & & \\
& & & & 393 & 0.286 & & \\
Female & 191 & 46.94 & 6.99972 & & &
\end{tabular}

Table 3 shows the data on the means, standard deviations and t-value of respondent's influence of social media on sexual behaviour of youth based on gender. The table shows that the calculated t-value of 0.268 is less than the critical t-value of 1.96 (p.value $0.77>0.05$ level of significance) on this basis, the null hypothesis which state that there is no significant difference in the influence of social media on sexual behaviour of youth in Kwara State based 
on gender was not rejected. This means that youth of different gender do not differ in their perception of the influence of social media on sexual behaviour of youth.

Hypothesis Two: There is no significant difference in the influence of social media on sexual behaviour of youth in Kwara State based on age.

\section{Table 4}

ANOVA Result showing the Difference in Response of Respondent's Influence of Social Media on Sexual Behaviour of Youth based on Age

\begin{tabular}{lllllll}
\hline $\begin{array}{l}\text { Sources of } \\
\text { Variance }\end{array}$ & $\begin{array}{l}\text { Sum of } \\
\text { Squares }\end{array}$ & Df & $\begin{array}{l}\text { Mean } \\
\text { Squares }\end{array}$ & $\begin{array}{l}\text { Cal. } \\
\text { F-value }\end{array}$ & $\begin{array}{l}\text { Crit. } \\
\text { F-value }\end{array}$ & p-value \\
\hline Between Groups & 226.99 & 3 & 75.66 & 1.50 & 2.60 & .213 \\
Within Groups & 19681.27 & 391 & 50.33 & & & \\
& & & & & \\
Total & 19908.26 & 394 & & & \\
\end{tabular}

Table 4 shows the data on the Analysis of Variance result showing the difference in response of respondent's influence of social media on sexual behaviour of youth based on age. The table shows that the calculated f-value of 1.50 is less than the critical t-value of 2.60 (p-value $.213>0.05$ level of significance). Therefore, the null hypothesis which states that there is no significant difference in the influence of social media on sexual behaviour of youth in Kwara State based on age was not rejected. This means that youth of different age ranges do not differ in their perception of the influence of social media on sexual behaviour of youth.

Hypothesis Three: There is no significant difference in the influence of social media on sexual behaviour of youth in Kwara State, based on the university attended. 


\section{Table 5}

ANOVA Result showing the Difference in Expression of Respondent's Influence of Social Media on Sexual Behaviour of Youth based on University Attended

\begin{tabular}{lllllll}
\hline Sources of Variance & Sum of Squares & df & Mean Squares & Cal. F-value & $\begin{array}{l}\text { Crit. F- } \\
\text { value }\end{array}$ & p-value \\
\hline Between Groups & 169.42 & 3 & 56.47 & 1.11 & 2.60 & 0.34 \\
Within Groups & 19738.84 & 391 & 50.48 & & & \\
Total & 19908.26 & 394 & & & & \\
\hline
\end{tabular}

Table 5 shows the data on the Analysis of Variance result showing the difference in response of respondent's influence of social media on sexual behaviour of youth based on university attended. The table shows that the calculated f-value of 1.11 is less than the critical t-value of 2.60 (p-value 0.34> 0.05 level of significance). Therefore, the null hypothesis which states that there is no significant difference in the influence of social media on sexual behaviour of youth in Kwara State based on university attended was not rejected. This means that youth of different universities do not differ in their perception of the influence of social media on sexual behaviour of youth.

\section{Discussion}

The findings of this study revealed that student involvement in the use of social media leads them to the act of sending erotic messages, watching pornographic films and movies and also increases risky sexual behaviour such as masturbation. This implies that students are making use of social media negatively at the expense of a lot of benefits they could derive from a positive usage of it. Students are always seen with their phones, tablets, ipad etc. Sometimes, students will be engrossed with the sexual content or message they are reading or viewing on their phones which makes them concentrate less on where they are heading to, 
which might cause an accident. Some students watch and exchange pornographic movies and view nude pictures whenever they are alone and will likely put all they have watched into practice. Other students spend most of their quality time, which they should have devoted to reading and online research that would help them academically, to downloading online sexual content and pornography. Some students view all these social media addictions as normal which results in them always being online. The result of this study is in line with Kirshner and Karpinski (2010) research on Facebook. Students' academic performance revealed that social media is commonly used among youth/students who exhibit carefree attitudes and luxurious living. They generally flout laws, easily copy bad attitudes, are disrespectful to parents and teachers, and are not serious about their academic works/studies. Also, Sofela (2012) posited that students are oftentimes observed using their mobile phones to communicate and do other social activities during school hours when they are expected to be engaged in meaningful activities.

More than $48 \%$ of Nigerian youth whose age range from 12 to 17 years use the internet and nearly half log on it daily (Lenhart, Madden \& Hitlin, 2005). Maeve (2014) also stated that the advent of the social media on mobile phones, Blackberry Messenger, Facebook, and Twitter has made Nigerian youth addicted to these gadgets and that they no longer have time for reading and preparing for their examinations. Ibrahim (2012) explained that the neglect of educational benefits has endangered students to becoming victims of sexual predators, cyber bullying and harassment, posting or downloading of inappropriate pictures and other materials which have affected them negatively in their reading habits and social life due to the amount of time dedicated to the social world.

Findings revealed that there was no significant difference in the influence of social media on sexual behaviour of youth in Kwara State based on gender. This means that there is 
The Influence of the Social Media on the Sexual Behavior of Youth in Kwara State, Nigeria

no difference in the influence that social media has on both male and female youth. The finding of this study is in contrast with the findings of Rafferty (2009) who posited that there is significant difference between girls and boys' usage of social media. The study noted that boys are also more likely to watch sexually explicit pictures and videos than girls and to talk about sexual activity publicly. The result of the findings may be attributed to the fact that students in foreign countries are exposed to technology and internet at earlier stages of life than students in Nigeria.

Another finding revealed that there was no significant difference in the influence of social media on the sexual behaviour of youth in Kwara State based on age. This means that there is no difference in the influence that social media has on different age groups of youth. The finding of this study contradicts the study of Sylvia, Moonhee and Sangwon (2013) which showed that different social media applications were perceived differently and that social media usage patterns and age affect these perceptions. The result of this study may be due to the fact that sex cannot be discussed publicly in Nigeria, unlike foreign countries where they get access to internet at an early age which exposes them to different social network sites where they can get involved in online sexual interactions.

Findings revealed that there was no significant difference in the influence of social media on the sexual behaviour of youth in Kwara State based on university attended. This means that social media has no influence on university attended by the youth. The finding of this study is similar to that of Eisenberg (2001) whose study revealed that social media has a greater influence on college students' sexual behaviour, which makes them exhibit most of the sexual acts they watch and see on social media. The result of this study may be due to the fact that students spend more of their time on social network sites. 


\section{Conclusion}

The findings of the study revealed that social media has more negative influences on youth because youth involvement in the use of social media usually results in the sending of erotic messages, watching pornographic films and movies, increases the exhibition of risky sexual behaviour, masturbation, and involvement in pre-marital sex. Also, there were no significant differences in the influence of social media on sexual behaviour of youth in Kwara State based on gender, age and university attended.

\section{Implications for Counselling Practice}

The findings of this study have implications for counselling practice. The responsibility of a professional counsellor is to inform clients on immediate and specific risk of significant harm or benefits to an identifiable phenomenon in order to prevent the harm and be able to accrue the benefits. Counsellors should help students through a range of strategies by developing safe, stable and nurturing relationships between students, their parents and guardians in order to reduce the availability and harmful use of social media and reduce the negative pressure peers place on one another.

Counsellors help to guide policy development that supports the ethical use of technology to aid in supporting students' holistic development. Therefore, university counsellors need to assist in developing policies for potential and prescribed interactions on social media that take place between educators, students, and families. Counsellors need to provide teaching life skills like assertive skills, decision making skills and also give students information on how to handle peer pressure and make positive use of social media.

Counsellors can provide preventive measures for students by organising workshops, orientation programs, seminars, student union week, talk shows and information materials (i.e. 
The Influence of the Social Media on the Sexual Behavior of Youth in Kwara State, Nigeria

using billboards) which will be placed at strategic places in the university environment, which will show the positive and negative influences of social media and peer pressure. Counsellors can also discuss with students the issue of how to imitate their peers positively and also how to communicate and define appropriate social media interactions for students and parents.

Counsellors can discourage students from the misuse of social media and peer pressure, and enhance their self-esteem by promoting empathy, ethical decision-making skills, and respect. Also, the introduction of awareness on internet safety strategies among students and their families could be provided by university counsellors. Finally, counsellors need to provide professional services that will be aimed at helping students who have fallen victim to social media addiction and peer pressure and how to handle it. Such remedial measures could include information services, rehabilitation services and many others.

\section{Recommendations}

Based on the findings of this study, the following recommendations were made:

1. Counsellors should expose students to the danger inherent in negative uses of social media, analyze the possible result of proper usage of social media, and tell them about some educative sites which can help them in all areas.

2. Counsellors could provide information specifically on the safe and respectful use of technology, as well as the consequences of the negative use of social media to students of different gender, age, religious affiliation and university attended.

3. The university counsellors should on a regular basis organize talk shows and seminars for students on the proper usage of social media and peer pressure. 


\section{References}

Boyd, D. M. \& Ellison, N. B. (2007). Social network sites: Definition, history, and scholarship. Journal of Computer Mediated Communication, 13, 210-230.

Braun-Courville. N. \& Rojas, A. M. (2009). Human development, family behaviour parenting, marriage and counselling skills. Enugu: Snapp Press Ltd.

Deczrlo J. E. (2009). Changing emphases in sexuality education in U.S. public secondary schools, 1988-1999. Family Planning Perspectives, 32(5),

Eisenberg, M. (2001). Differences in sexual risk behaviours between college students with same-sex and opposite-sex experience: Results from a national survey. Archives of Sexual Behaviour, 30, 575-89.

Emma-Slaymaker, Walker, N. H., Zaba, B. \& Collumbian, M. (2009). Unsafe sex in global health risks. Mortality and Burden of Disease Attributable to Selected Major Risks. WHO, Geneva, 1178-1254.

Fawole, A. O., Ogunkan, D. V. \& Adegoke, G. S. (2011). Sexual behaviour and perception of HIV/AIDS in Nigerian tertiary institutions: University of Ilorin a Case Study. Global Journal of Human Social Science, 11, 1.

Fischer, F. \& Mandl, H. (2005). Knowledge convergence in computer-supported collaborative learning: The role of external representation tools. The Journal of the Learning Sciences, 14, 405-441.

Greenhow, C., Robelia, B. \& Hughes, J. E. (2009). Learning, teaching, and scholarship in a digital age Web 2.0 and classroom research: What path should we take now? Educational Researcher, 38, 246-259.

Harris, A. L. \& Rea, A. (2009). Web 2.0 and virtual world technologies: A growing impact on US education. Journal of Information Systems Education, 20, 45-46

Ibrahim, L. (2012). Social media and its influence on students' performance. Jamb News, $3(21), 4-5$.

Kaplan, M. A. \& Haenlein, M. (2010). Users of the world unite: The challenges and opportunities of social media. Business Horizones, 53(1), 59-68.

Kirby, D., Raine, T., Thrush, G., Yuen, C., Sokoloff, A., \& Potter, S. C. (2010). Impact of an intervention to improve contraceptive use through follow-up phone calls to female youth clinic patients. Perspectives on Sexual and Reproductive Health, 42(4), 251257.

Kirshner, P. A. \& Karpinski, A. C. (2010). Facebook and academic performance, online interactivity: Role of technology in behaviour change. Computers in Human Behaviour, 26(6), 1237-1245. 
The Influence of the Social Media on the Sexual Behavior of Youth in Kwara State, Nigeria

Lenhart, A., Madden, M., \& Hitlin, P. (2005). Teens and technology: Youth are leading the transition to a fully wired and mobile nation. Retrieved October 13, 2005, fromhttp://www.pewInternet.org/pdfs/

Maeve, O. (2014). History of science and history of translation: Disciplinary commensurably. The Translator, 20(1), 9-25.

National Population Commission (NPC) Nigeria (2015). Nigeria demographic and health Survey. Calverton. Retrieved fromhttp://www.cdc.gov/mmwr/pdf/ss/ss6104.pdf

Onwuasoanya, P. N. (2008). Counseling psychology for Nigeria. Nsukka: Great AP Express Publishers Limited.

Rafferty, F. (2009). Boys should be boys-is it that simple? Education Journal.

Redecker, C, Ala-Mutka, K, Bacigalupo, M, Ferrari, A. \& Punie, Y. (2009). Learning 2.0: The impact of Web 2.0 innovations on education and training in Europe. Final Report: European Commission-Joint Research Center-Institute for Perspective Technological Studies, Seville.

Research Advisor (2006). Required sample size. Retrieved from http//www google.com.

Sofela, R. (2012). How to understand and confront hate speech. Retrieved from http://www.How-to- understand-and-confront-hate-speech.htm.

Sylvia, M. C., Moonhee, C. \& Sangwon, L. (2013). User perceptions of social media: A Comparative Study of Perceived Characteristics and User Profiles by Social Media University of Florida, USA. Online Journal of Communication and Media Technologies Volume: 3 - Issue: 4 - October - 2013

Wang, X., Chunling, Y. \& Yujie, W. (2012). Social media, peer communication and impacts on purchase intentions: A consumer socialization framework. Journal of Interactive Marketing, 26, 198-208.

World Health Organization (2012). Sexual health. Retrieved 5/16/2012, 2012, from http://www.who.int/topics/sexual_health/en/ 